\title{
Utilization of knife fish bone (Chitala chitala) as a material for fish protein and mineral powder production by enzyme hydrolysis
}

\author{
Thuy T. M. Le ${ }^{1 *}, \&$ Truc T. Tran ${ }^{2}$ \\ ${ }^{1}$ College of Aquaculture and Fisheries, Can Tho University, Can Tho, Vietnam \\ ${ }^{1}$ College of Agriculture, Can Tho University, Can Tho, Vietnam
}

ARTICLE INFO
Research Paper
Received: February 26, 2019
Revised: May 15, 2019
Accepted: July 22, 2019

Keywords

Enzyme hydrolysis

Knife fish bone

Mineral powder

Protein powder

* Corresponding author

Le Thi Minh Thuy

Email: ltmthuy@ctu.edu.vn

\begin{abstract}
Utilization of knife fish bone as new materials to produce fish protein and mineral powder to increase the value of by-products is necessary. The objective of this study was to investigate effects of Tegalase enzyme concentration, heating time, and drying condition on the quality of hydrolyzed knife fish bone. The results showed that the sample hydrolyzed at $50^{\circ} \mathrm{C}$ with the Tegalase enzyme concentration of $0.3 \%$ resulted in the highest peptide formation and amino acid content in protein solution (3602 peptide bonding and $16.4 \mathrm{~g} / \mathrm{L}$, respectively) as well as the highest mineral content $(38.8 \%)$ in the bone sample. After hydrolysis, the sample was filtered to separate the bone and protein solution. The protein solution heated up to $90-100^{\circ} \mathrm{C}$ for $2 \mathrm{~min}$ showed the highest amino acid content $(18.1 \mathrm{~g} / \mathrm{L})$. The moisture content, protein yield and recovery yield of the fish protein were $9.11 \%, 68.1 \%$, and $2.19 \%$, respectively when dried at $60^{\circ} \mathrm{C}$ for $24 \mathrm{~h}$. After hydrolysis, the bone was dried at the temperature of $60^{\circ} \mathrm{C}$ for $3 \mathrm{~h}$ to get mineral powder with $11.4 \%$ moisture, $78.9 \%$ minerals and $21.9 \%$ calcium.
\end{abstract}

Cited as: Le, T. T. M., \& Tran, T. T. (2019). Utilization of knife fish bone (Chitala chitala) as a material for fish protein and mineral powder production by enzyme hydrolysis. The Journal of Agriculture and Development 18(4), 33-41. 


\title{
Nghiên cứu tận dụng xương cá thác lác còm (Chitala chitala) để sản xuất bột đạm và bột khoáng bằng phương pháp thủy phân enzyme
}

\author{
Lê Thị Minh Thủy ${ }^{1 *} \&$ Trần Thanh Trúc ${ }^{2}$ \\ ${ }^{1}$ Khoa Thủy Sản, Trường Đại Học Cần Thơ, Cần Thơ \\ ${ }^{2}$ Khoa Nông Nghiệp, Trường Đại Học Cần Thơ, Cần Thơ
}

\section{THÔNG TIN BÀI BÁO}

Bài báo khoa học

Ngày nhận: 26/02/2019

Ngày chỉnh sửa: 15/05/2019

Ngày chấp nhận: 22/07/2019

Từ khóa

Bột đạm

Bột khoáng

Thủy phân enzyme

Xương cá thác lác còm

*Tác giả liên hệ

Lê Thị Minh Thủy

Email: ltmthuy@ctu.edu.vn

\section{TÓM TẮT}

Tận dụng xương cá thác lác như nguồn nguyên liệu mới để sản xuất bột đạm và bột khoáng nhằm nâng cao giá trị nguồn phụ phẩm này là cần thiết. Mục tiêu của nghiên cứu nhằm khảo sát ảnh hưởng của nồng độ enzyme Tegalase, thời gian nâng nhiệt và quá trình sấy đến chất lượng sản phẩm. Kết quả cho thấy khi thủy phân mẫu ở nhiệt độ $50^{\circ} \mathrm{C}$ trong 24 giờ ở nồng độ enzyme Tegalase $0,3 \%$ thì tạo ra dịch đạm có sự hình thành peptit (3602 liên kết peptit) và hàm lượng axít amin $(16,4 \mathrm{~g} / \mathrm{L})$ nhiều nhất cung như hàm lượng khoáng trong xương $(38,8 \%)$ cao nhất. Mẫu sau khi thủy phân được lọc để thu phần xương và dịch đạm. Dịch đạm được nâng nhiệt ở nhiệt độ $90-100^{\circ} \mathrm{C}$ trong khoảng 2 phút cho hàm lượng axit amin là cao nhất $(18,1 \mathrm{~g} / \mathrm{L})$ ). Sau đó, dịch đạm được sấy ở $60^{\circ} \mathrm{C}$ trong 24 giờ thu được bột đạm với độ ẩm là $9,11 \%$, hàm lượng protein là $68,1 \%$ và hiệu suất thu hồi là $2,19 \%$. Bột khoáng thu được có độ ẩm thích hợp là $11,4 \%$, hàm lượng khoáng là 78,9\%, hàm lượng canxi đạt $21,9 \%$ khi sấy mẫu xương sau thủy phân ở $60^{\circ} \mathrm{C}$ trong 3 giờ.

\section{1. Đặt Vấn Đề}

Những năm gần đây, cá thác lác còm được nhân giống và nuôi rộng rãi ở các tỉnh đồng bằng sông Cửu Long như An Giang, Cần Thơ, đặc biệt là Hậu Giang vừa mang lại hiệu quả kinh tế cao vừa đáp ứng nhu cầu tiêu thụ trong nước và xuất khẩu. Tuy nhiên, sau khi tách thịt thì lượng phụ phẩm thải ra môi trường rất lớn chiếm từ $50-75 \%$ (Tran, 2014). Vì thế, nếu xử lý không triệt để sẽ dễ gây ô nhiễm môi trường do tính chất thủy sản mau ươn thối, gây mùi khó chịu. Về hướng xử lý phụ phẩm, có thể dùng chế biến bột cá trong chăn nuôi, dầu cá giàu dinh dưỡng,... Tuy nhiên, các hướng xử lý này vẫn chưa tận dụng phế phẩm một cách hiệu quả. Xương cá là nguồn tiềm năng cung cấp canxi - một nguyên tố rất cần cho sức khỏe con người và chiếm từ $34-36 \%$ tổng hàm lượng khoáng có trong xương (Hamada \& ctv., 1995), đồng thời khai thác triệt để lượng thịt vụn còn sót lại khá cao trên xương tạo ra nguồn đạm có tính ứng dụng rộng rãi trong ngành công nghệ thực phẩm. Phương pháp thủy phân thịt hay xương cá bằng enzyme đang được lựa chọn nhiều nhất do mang lại hiệu quả thủy phân cao, tạo ra sản phẩm giá trị dinh dưỡng cao, cho hiệu suất thu hồi tốt (Kristinsson \& Rasco, 2000; Gao \& ctv., 2006) và là bước tiến mới của ngành thủy sản nước ta nhằm tạo ra sản phẩm đảm bảo chất lượng dinh dưỡng, đáp ứng yêu cầu con người hiện đại. Nhiều loại enzyme được nghiên cứu rộng rãi để thủy phân nguồn protein từ cá như Alcalase, Neutrase, Protamex, Flavourzyme cho hiệu quả thủy phân tốt (Kristinsson \& Rasco, 2000; Liaset \& ctv., 2002; Muzaifa \& ctv., 2012). Tuy nhiên, các nghiên cứu ứng dụng enzyme Tegalase để thủy phân protein còn khá hạn chế và gần như chưa có công bố nào về khả năng thủy phân của loại enzyme này. Chính vì những lý do trên, nghiên cứu thủy phân xương cá thác lác còm (Chitala chitala) để sản xuất bột đạm và bột khoáng bằng enzyme Tegalase đã được thực hiện. 


\section{Vật Liệu và Phương Pháp Nghiên Cứu}

\subsection{Chuẩn bị mẫu}

Nguyên liệu là xương cá thác lác còm thu tại công ty cổ phần thực phẩm Phạm Nghĩa, Cần Thơ được vận chuyển về phòng thí nghiệm bộ môn Chế biến Thủy sản, khoa Thủy sản, Trường Đại học Cần Thơ. Nguyên liệu được rửa sạch loại bỏ tạp chất, để ráo và cắt nhỏ khoảng 2 - $3 \mathrm{~cm}$. Sau đó, mẫu được đóng gói trong túi $\mathrm{PE}$, khối lượng mỗi mẫu là $500 \mathrm{~g}$ và bảo quản trong tủ đông (nhiệt độ $\leq-18^{0} \mathrm{C}$ ) để đảm bảo chất lượng cho đến khi tiến hành các thí nghiệm. Enzyme Tegalase (Tegaferm Holding GmBh, Áo) thủy phân protein thành axit amin có $\mathrm{pH}$ tối thích là $7,8-8,8$ và hoạt động trong miền nhiệt độ $50-60^{\circ} \mathrm{C}$.

2.2. Khảo sát sự ảnh hưởng của nồng độ enzyme đến chất lượng dịch đạm và hàm lượng khoáng trong xương cá thác lác còm

Mẫu xương cá thác lác còm đã chuẩn bị trước đó được rã đông, tiến hành thủy phân xương cá bằng enzyme Tegalase với các nồng độ khác nhau lần lượt là 0,$1 ; 0,2$ và $0,3 \%$ so với nguyên liệu $(\mathrm{v} / \mathrm{w})$, enzyme được trộn chung với nước cất và lắc đều trước khi cho dung dịch enzyme này vào mẫu thí nghiệm nhằm tạo điều kiện cho enzyme tiếp xúc đều với cơ chất, nước cất được sử dụng bằng $10 \%$ so với khối lượng mẫu xương. Giữ nhiệt độ ổn định trong suốt quá trình thủy phân là $50^{0} \mathrm{C}$. Thời gian thủy phân là 24 giờ. Kêt thúc quá trình thủy phân tiến hành lọc để phân thành hai phần là dịch đạm và xương. Phân tích độ ẩm, hàm lượng đạm và khoáng trên mẫu xương; phân tích hàm lượng axit amin và số liên kết peptit tạo thành trên mẫu dịch đạm nhằm tìm ra nồng độ enzyme thích hợp để hiệu quả thủy phân là tốt nhất. Thí nghiệm được khảo sát thông qua một nhân tố (nồng độ enzyme Tegalase) với khối lượng mỗi mẫu là $200 \mathrm{~g} /$ nghiệm thức. Thí nghiệm được lặp lại 3 lần ở mỗi nghiệm thức.

2.3. Khảo sát sự ảnh hưởng của thời gian nâng nhiệt đến quá trình thủy phân protein thành axit amin

Mẫu sau khi thủy phân với nồng độ enzyme Tegalase thích hợp (kết quả thí nghiệm 1). Phần dịch đạm được nâng nhiệt bằng incubate lên nhiệt độ $90-100^{\circ} \mathrm{C}$ và giữ nhiệt ở nhiệt độ này trong các mốc thời gian lần lượt là 2,4 và 6 phút. Sau khi nâng nhiệt xong, mẫu được kiểm tra $\mathrm{pH}$ bằng giấy quỳ, nếu $\mathrm{pH}$ môi trường axit thì dùng $\mathrm{NaOH}$ $3 \%$ để trung hòa đến môi trường trung tính. Sau đó, mẫu được phân tích hàm lượng axit amin nhằm chọn được thời gian nâng nhiệt thích hợp dể quá trình thủy phân protein thành axit amin là tốt nhất. Thí nghiệm được khảo sát thông qua một nhân tố (thời gian nâng nhiệt) với khối lượng mỗi mẫu là $200 \mathrm{~g} /$ nghiệm thức. Thí nghiệm được lặp lại 3 lần ở mỗi nghiệm thức.

\subsection{Khảo sát sự ảnh hưởng của thời gian sấy đến ẩm độ, hàm lượng đạm và hiệu suất thu hồi của sản phẩm bột đạm}

Mẫu dịch đạm sau khi nâng nhiệt ở thí nghiệm 2 sẽ tiếp tục được phân ly để thu hồi phần đạm cho thí nghiệm sấy. Mẫu được sấy bằng thiết bị sấy không khí nóng (Tủ sấy đối lưu tự nhiên ED 400 Binder, Đức) với các mốc thời gian là 24,48 và 72 giờ ở nhiệt độ $60^{\circ} \mathrm{C}$. Sau khi sấy, tiến hành phân tích ẩm độ, hàm lượng đạm và hiệu suất thu hồi nhằm tìm ra thời gian sấy thích hợp để bột đạm có hàm lượng protein cao, độ ẩm thích hợp và hiệu suất thu hồi cao. Thí nghiệm được khảo sát thông qua một nhân tố (thời gian sấy) với khối lượng mỗi mẫu là $200 \mathrm{~g} /$ nghiệm thức. Thí nghiệm được lặp lại 3 lần ở mỗi nghiệm thức.

\subsection{Khảo sát sư ảnh hưởng của thời gian thời gian sấy đển ẩm độ, độ hòa tan và hiệu suất thu hồi của sản phẩm bột khoáng}

Mẫu xương sau khi thủy phân với nồng độ enzyme Tegalase thích hợp (kết quả thí nghiệm 1) được sấy ở $60^{\circ} \mathrm{C}$ bằng thiết bị sấy đối lưu tự nhiên ED 400 Binder (Đức) trong các mốc thời gian 2, 3 và 4 giờ. Kết thúc quá trình sấy tiến hành phân tích lại độ ẩm, độ hòa tan và hiệu suất thu hồi nhằm tìm ra chế độ sấy thích hợp nhất để sản phẩm bột khoáng đạt chất lượng tốt nhất, có khả năng hòa tan tốt, hiệu suất thu hồi cao và đạt ẩm độ theo yêu cầu. Thí nghiệm được khảo sát thông qua một nhân tố (thời gian sấy) với khối lượng mỗi mẫu là $200 \mathrm{~g} /$ nghiệm thức. Thí nghiệm được lặp lại 3 lần ở mỗi nghiệm thức.

\subsection{Phương pháp phân tích}

Xác định tổng vi sinh vật hiếu khí có trong mẫu bằng phương pháp đổ đĩa (AOAC, 990.12), hàm lượng ẩm bằng phương pháp sấy (AOAC 
934.01, 2000), hàm lượng khoáng bằng phương pháp nung $(923.03,2000)$, hàm lượng đạm tổng số bằng phương pháp Kjehdal, hàm lượng lipid bằng phương pháp Soxhlet (AOAC 920.39, 2000). Thành phần hóa học (ẩm, khoáng, protein, lipid) của mẫu nguyên liệu đầu vào được phân tích dựa trên căn bản khô (vật chất khô), còn đối với sự biến đổi thành phần của mẫu trong các bố trí thí nghiệm được phân tích dựa trên căn bản ướt.

Xác định hàm lượng axit amin bằng phương pháp Nitơ formol được mô tả theo tiêu chuẩn TCVN 3708-1990.

Xác định số liên kết peptid theo phương pháp Hultmann \& ctv. (2012). Cho 1,2 mL dung dịch đệm ở mức pH $(5,5$ hoặc 7,5$)$ (acid citric $0,1 \mathrm{M}$ và natri hydrophosphate $0,2 \mathrm{M}$ ) vào ống nghiệm $15 \mathrm{~mL}$, tiếp tục cho vào $0,1 \mathrm{~mL}$ mẫu lắc đều. Sau đó thêm $2 \mathrm{~mL}$ trichloroacetic acid (TCA $5 \%$ ) vào để làm kết tủa protein, lắc đều và để yên 30 phút. Sau đó tiến hành lọc để bỏ kết tủa, thu phần dịch lọc. Hút $0,5 \mathrm{~mL}$ dung dịch vừa lọc được cho vào ồng nghiệm, sau đó thêm vào $2,5 \mathrm{~mL}$ dung dịch $\mathrm{D}$ ( $1 \mathrm{~mL}$ dung dịch $\mathrm{CuSO}_{4} 1 \%+1 \mathrm{~mL}$ Potassium Sodium Tartrate $2 \%+100 \mathrm{~mL} \mathrm{Na}_{2} \mathrm{CO}_{3} 2 \%$ trong $0,1 \mathrm{M} \mathrm{NaOH})$, lắc đều và để yên 10 phút, cuối cùng thêm $0,25 \mathrm{~mL}$ Folin (pha loãng với nước tỷ lệ 1folin: 2 nước, v:v) lắc đều, để yên sau 30 phút tiến hành đo màu quang phổ với bước sóng 750 nm. Mẫu dùng cho cài đặt máy quang phổ cũng được chuẩn bị bằng cách cho $0,5 \mathrm{~mL}$ nước cất và $2,5 \mathrm{~mL}$ dung dịch, lắc đều và để yên 10 phút cuối cùng thêm $0,25 \mathrm{~mL}$ Folin $(1: 2)$ lắc đều, để yên 30 phút dùng làm mẫu trắng so màu với mẫu thí nghiệm.

Xác định độ hòa tan bằng phương pháp lọc theo phương pháp của Hemung (2013). Xác định độ hòa tan của sản phẩm theo công thức $\mathrm{T}=((\mathrm{D}$ $-\mathrm{C}) \times 100) / \mathrm{D}$. Trong đó: T là độ hòa tan của sản phẩm, D là khối lượng bột cá ban đầu và $\mathrm{C}$ là khối lượng bột cá không tan. Cân $1 \mathrm{~g}$ bột cá (D) hòa tan với $10 \mathrm{~mL}$ nước cất. Sau đó, khuấy đều trong 12 giờ, nhiệt độ phòng. Lọc dung dịch qua giấy lọc, sau đó sấy giấy lọc và mẫu đến khối lượng không đổi, cân để xác định khối lượng mẫu còn lại $(\mathrm{C})$.

Xác định hàm lượng canxi theo AOAC 2013.06 (2016).

Xác định hiệu suất thu hồi bằng phương pháp kiểm tra khối lượng sản phẩm theo công thức:

$$
\mathrm{H}=\frac{\mathrm{Y}}{\mathrm{X}} \times 100 \%
$$

\section{Trong đó:}

$\mathrm{H}(\%)$ : Hiệu suất thu hồi của sản phẩm.

Y (g): Khối lượng bột cá hoặc bột canxi thu được sau sây.

X (g): Khối lượng mẫu đem đi thủy phân.

\subsection{Xử lý số liệu}

Kết quả được tính toán trung bình, độ lệch chuẩn bằng chương trình Microsoft Excel 2013. Xử lý thống kê One Way ANOVA với mức ý nghĩa $95 \%$ bằng chương trình SPSS 16.0. So sánh sự khác biệt giữa các nghiệm thức trong cùng một thí nghiệm bằng phép thử Duncan.

\section{Kết Quả và Thảo Luận}

\subsection{Thành phần hóa học của nguyên liệu xương cá thác lác còm}

Kết quả phân tích thành phần hóa học của xương cá thát lát còm được thể hiện trong Bảng 1.

Bảng 1. Thành phần hóa học xương cá thác lác còm (tính theo vật chất khô)

\begin{tabular}{lc}
\hline Chỉ tiêu & Hàm lượng $(\%)^{1}$ \\
\hline Khoáng & $43,6 \pm 0,87$ \\
Protein & $36,3 \pm 0,01$ \\
Lipid & $8,92 \pm 1,70$ \\
\hline
\end{tabular}

${ }^{1}$ Số liệu được trình bày dưới dạng trung bình \pm độ lệch chuẩn, $\mathrm{n}=3$.

Kết quả ở Bảng 1 cho thấy thành phần hóa học chủ yếu của xương cá thác lác còm là khoáng và đạm chiếm hàm lượng cao lần lượt là 43,6 và $36,3 \%$. Với hàm lượng cao khoáng và đạm, xương cá thát lát là nguồn nguyên liệu thích hợp để tận dụng sản xuất bột đạm và bột khoáng có chất lượng cao.

\subsection{Xác định nồng độ enzyme Tegalase thích hợp để đạt được hiệu quả thủy phân cao nhất}

Chất lượng dịch đạm thu được từ công đoạn thủy phân xương cá thát lát còm tương ứng với các nồng độ enzyme Tegalase khác nhau được trình bày ở Bảng 2 .

Kết quả thủy phân được thể hiện ở Bảng 2 cho thấy ở các nồng độ enzyme khác nhau thì hiệu quả thủy phân cũng khác nhau. Đối với mẫu 
Bảng 2. Ảnh hưởng của tỷ lệ enzyme Tegalase đến chất lượng dịch đạm

\begin{tabular}{cccc}
\hline Mẫu & Tỷ lệ enzyme $(\%)$ & Số liên kết peptit (liên kết) & Hàm lượng axit amin(g/L) \\
\hline Đối chứng & 0 & $1234 \pm 9,87^{\mathrm{a}}$ & $8,05 \pm 0,099^{\mathrm{a}}$ \\
1 & 0,1 & $2986 \pm 16,8^{\mathrm{b}}$ & $11,9 \pm 0,297^{\mathrm{b}}$ \\
2 & 0,2 & $3752 \pm 9,51^{\mathrm{c}}$ & $13,6 \pm 0,001^{\mathrm{c}}$ \\
3 & 0,3 & $3602 \pm 5,43^{\mathrm{c}}$ & $16,4 \pm 0,001^{\mathrm{d}}$ \\
\hline
\end{tabular}

a-d Trong cùng một cột, những số có chữ theo sau khác nhau thì có khác biệt ý nghĩa thống kê ở mức $5 \%$.

đối chứng chưa bổ sung enzyme thì quá trình thủy phân vẫn diễn ra dưới tác dụng của hệ enzyme protease nội tại, nhưng số liên kết peptit tạo thành thấp (1234 liên kết). Khi tăng tỷ lệ enzyme Tegalase bổ sung vào mẫu từ 0,1 đến $0,3 \%$ thì khả năng thủy phân protein tạo thành liên kết peptit cũng tăng dần từ 2986 dến 3602 liên kết. Đồng thời, khi tăng tỷ lệ enzyme thì hàm lượng axit amin trong dịch đạm tăng từ 11,9 đến 16,4 g/L. Nguyên nhân là dưới tác dụng của enzyme, protein bị thủy phân, nghĩa là phân tử protein bị phân cắt tại các liên kết peptit tạo thành các chuỗi peptit mạch ngắn, sau đó các mạch peptit tiếp tục được phân cắt tạo thành các axit amin và làm tăng hàm lượng axit amin và số liên kết peptit tạo thành cũng tăng khi tăng tỷ lệ enzyme bổ sung (Nguyen, 2004; Dang, 2008). Tuy nhiên, sự có mặt của các chuỗi peptit mạch ngắn mới được sinh ra cũng làm ức chế phần nào tác dụng thủy phân của enzyme (Guérard \& ctv., 2002; Ogawa \& Shimizu, 2002) và có thể đóng vai trò là đối thủ cạnh tranh cơ chất hiệu quả đối với các protein chưa được thủy phân hoặc thủy phân một phần (Nguyen \& ctv., 2011). Kết quả nghiên cứu của Nguyen \& ctv. (2013) thì với tỉ lệ enzyme Alcalase là $0,382 \%$, nhiệt độ thủy phân là $62^{\circ} \mathrm{C}$ và thời gian thủy phân là 2 giờ sẽ cho hàm lượng đạm hòa tan cao $(18,5 \mathrm{~g} / \mathrm{L})$ từ quá trình thủy phân đầu tôm thẻ chân trắng. Ở nghiên cứu của Do \& ctv. (2013) cũng cho kết quả thủy phân tốt khi bổ sung enzyme Flavourzyme ở nồng độ $0,5 \%$ so với khối lượng nguyên liệu, nhiệt độ $50^{\circ} \mathrm{C}$ và thủy phân trong 6 giờ sẽ cho ra sản phẩm thủy phân protein từ đầu cá chẽm chứa hàm lượng axit amin cao $(44,02 \mathrm{~g} / 100 \mathrm{~g}$ chất khô) và tỉ lệ axit amin không thay thế cao (47,71\%). Một kết quả khác của tác giả $\mathrm{Vu}$ (2004) đã nghiên cứu quá trình thủy phân protein cá mối (Saurida Tumbil) để thu hồi bột đạm bằng protease từ vi khuẩn Bacillus subtilis và cho thấy hệ enzyme này đã thực hiện tốt quá trình thủy phân cơ thịt cá mối với nồng độ $0,3 \%$ ở $50^{\circ} \mathrm{C}$. Ẩm độ, hàm lượng khoáng và protein của xương cá sau khi thủy phân bằng enzyme ở các nồng độ khác nhau thể hiện trong Bảng 3 .

Bên cạnh đó, khi thủy phân mẫu xương với tỷ lệ enzyme tăng từ 0,1 đến $0,3 \%$ thì hàm lượng ẩm, khoáng và protein cũng thay đổi đáng kể. Cụ thể, khi tỷ lệ enzyme tăng dần thì hàm lượng ẩm giảm dần từ 41,2 còn $35,1 \%$, hàm lượng protein trong xương cũng giảm dần từ 10,6 còn $8,93 \%$ dồng thời hàm lượng khoáng tăng dần từ 35,6 đến 38,8\%. Nguyên nhân chủ yếu là do trong quá trình thủy phân phần thịt vụn trên xương bị phân cắt mạch thành các chuỗi peptit mạch ngắn và axit amin cùng với lượng nước tự do trong nguyên liệu cũng được thoát ra một phần làm hàm lượng đạm trên xương giảm đáng kể và hàm lượng khoáng tăng (Le, 2002). Trước đây vẫn chưa có nhiều nghiên cứu sử dụng enzyme để thủy phân loại protein ra khỏi xương mà chủ yếu là sử dụng phương pháp truyền thống, dùng nhiệt độ cao trong nồi áp suất và sử dụng hóa chất để loại protein trong mẫu xương. Nghiên cứu của Techochatchawal \& ctv. (2009) đã đề xuất xương cá rô phi (Tilapia nilotica) được xử lý bằng $\mathrm{NaOH} 0,8 \%$, tỉ lệ 1:5 (w/v), sau đó xương được gia nhiệt ở $121^{\circ} \mathrm{C}$ trong 90 phút, 1,02 atm cho chất lượng bột canxi tốt nhất với hàm lượng canxi là $25,01 \%$, còn đối với xương cá hồi và cá tuyết sản xuất bột canxi (Bubel \& ctv., 2015) sử dụng $\mathrm{NaOH} 2 \mathrm{M}$ với thời gian lần lượt là 12 và 24 giờ làm protein giảm từ 18,0 xuống 10,8\% (đối với xương cá hồi), 15,3 xuống $14,2 \%$ (đối với xương cá tuyết). Nghiên cứu được công bố bởi Nemati \& ctv. (2017) cũng xử lý xương cá ngừ (Thunnus albacares) bằng dung dịch $\mathrm{NaOH} 2 \%$ trong 30 phút ở nhiệt độ sôi với tỉ lệ 1:3 (w/v). Vì thế, so với phương pháp cũ thì phương pháp sử dụng enzyme bổ sung để thủy phân xương cá là một bước tiến mới góp phần tiết kiệm thời gian chi phí cũng như mang lại hiệu quả khử protein cao và hạn chế ô nhiễm môi trường. Như vậy, kết hợp với chất lượng dịch đạm sau thủy phân ở Bảng 2 thì nồng độ bổ sung enzyme Tegalase $0,3 \%$ là thông số thích hợp để bố trí thí nghiệm tiếp theo. 
Bảng 3. Ảnh hưởng của tỷ lệ enzyme Tegalase đến thành phần hoá học của xương cá thác lác sau quá trình thủy phân (tính theo căn bảng ướt)

\begin{tabular}{ccccc}
\hline Mẫu & Tỷ lệ enzyme (\%) & Ẩm độ $(\%)$ & Khoáng $(\%)$ & Protein $(\%)$ \\
\hline Đối chứng & 0,0 & $58,1 \pm 2,29^{\mathrm{b}}$ & $12,4 \pm 0,053^{\mathrm{a}}$ & $14,2 \pm 0,233^{\mathrm{a}}$ \\
1 & 0,1 & $41,2 \pm 0,893^{\mathrm{a}}$ & $35,6 \pm 1,55^{\mathrm{b}}$ & $10,6 \pm 0,158^{\mathrm{b}}$ \\
2 & 0,2 & $41,1 \pm 3,24^{\mathrm{a}}$ & $36,0 \pm 3,55^{\mathrm{b}}$ & $10,1 \pm 0,631^{\mathrm{b}}$ \\
3 & 0,3 & $35,1 \pm 6,39^{\mathrm{a}}$ & $38,8 \pm 3,06^{\mathrm{b}}$ & $8,93 \pm 0,149^{\mathrm{c}}$ \\
\hline
\end{tabular}

a-c Trong cùng một cột, những số có chữ theo sau khác nhau thì có khác biệt ý nghĩa thống kê ở mức $5 \%$.

\section{3. Ảnh hưởng của thời gian nâng nhiệt đến quá trình thủy phân protein thành axit amin}

Hàm lượng đạm amin trong mẫu dịch đạm sau khi nâng nhiệt được trình bày trong Bảng 4 .

Bảng 4. Ảnh hưởng của thời gian nâng nhiệt đến sự thủy phân dịch đạm thành các axit amin

\begin{tabular}{ccc}
\hline Mẫu & $\begin{array}{c}\text { Thời gian nâng } \\
\text { nhiệt (phút) }\end{array}$ & $\begin{array}{c}\text { Axit amin } \\
(\mathrm{g} / \mathrm{L})\end{array}$ \\
\hline Đối chứng & 0 & $16,4 \pm 0,001^{\mathrm{a}}$ \\
1 & 2 & $18,1 \pm 0,001^{\mathrm{d}}$ \\
2 & 4 & $17,3 \pm 0,099^{\mathrm{c}}$ \\
3 & 6 & $16,6 \pm 0,049^{\mathrm{b}}$ \\
\hline
\end{tabular}

$\overline{\mathrm{a}-\mathrm{d}}$ TTrong cùng một cột, những số có chữ theo sau khác nhau thì có khác biệt ý nghĩa thống kê ở mức $5 \%$.

Kết quả ở Bảng 4 cho thấy rằng khi tăng thời gian nâng nhiệt lên 2 phút thì hàm lượng axit amin trong mẫu dịch đạm tăng từ 16,4 đến 18,1 $\mathrm{g} / \mathrm{L}$. Tuy nhiên khi tiếp tục nâng nhiệt đến 4 và 6 phút thì hàm lượng axit amin thu được lại có khuynh hướng giảm. Nguyên nhân chủ yếu của sự thay đổi này là trong quá trình thủy phân có thể chưa đủ điều kiện thích hợp để cắt mạch protein hoàn toàn thành axit amin nên trong thời gian nâng nhiệt 2 phút sẽ là điều kiện bắt buộc để protein bị cắt mạch hoàn toàn, khi tiếp tục tăng thời gian nâng nhiệt thì axit amin có trong mẫu bắt đầu biến tính sinh ra các sản phẩm cấp thấp làm hao hụt hàm lượng amino axit. Điều này cho thấy nhiệt độ càng cao và thời gian nâng nhiệt càng dài thì hàm lượng axit amin càng giảm. Nguyên nhân là do enzyme có bản chất là protein nên bị biến tính bởi nhiệt độ cao (Nguyen, 2009), Tuy nhiên, mục đích của công đoạn nâng nhiệt là làm đông vón protein, phá vỡ cấu trúc của dầu, làm protein tách ra dễ dàng, giảm bớt mùi và làm mất hoạt tính của enzyme, tạo thuận lợi cho công đoạn sấy sản phẩm vì vậy hạn chế được sự hư hỏng và tạo mùi đặc trưng cho sản phẩm (Le, 2014). Dựa vào kết quả xử lý thống kê ở thời gian từ 0 đến 6 phút thì ở các mốc thời gian đều khác biệt có ý nghĩa thống kê và ở mốc thời gian 2 phút cho hàm lượng axit amin cao nhất $(18,1 \mathrm{~g} / \mathrm{L})$ nên chọn 2 phút để nâng nhiệt vừa đạt yêu cầu đặt ra của thí nghiệm vừa rút ngắn thời gian và có lợi về mặt kinh tế.

\section{4. Ảnh hưởng của thời gian sấy đến chất lượng bột đạm}

Độ ẩm, hàm lượng đạm và hiệu suất thu hồi của sản phẩm bột đạm ở các mốc thời gian sấy khác nhau được trình bày ở Bảng 5 .

Kết quả cho thấy, sấy mẫu ở cùng một nhiệt độ $60^{\circ} \mathrm{C}$ khi tăng thời gian sấy từ 2 dến 4 ngày thì hàm lượng ẩm trong nguyên liệu giảm dần từ 12,2 còn $6,36 \%$, sự khác biệt này có ý nghĩa thống kê giữa các mẫu, hiệu suất thu hồi giảm từ 2,25 còn $2,14 \%$ và hàm lượng đạm tăng từ 66,3 đến $78,2 \%$. Nguyên nhân chủ yếu do sấy ở nhiệt độ cao trong một thời gian dài, dưới tác dụng của nhiệt thì nước tự do trong mẫu sẽ dễ dàng bay hơi làm ẩm độ giảm nhanh chóng và hàm lượng chất khô (hàm lượng protein) trong mẫu đạm sẽ tăng lên, tuy nhiên nếu tiếp tục sấy thì nước còn lại trong nguyên liệu chủ yếu là nước liên kết nên rất khó thoát ra ngoài (Nguyen, 1990). Theo Le (2014) độ ẩm thích hợp của sản phẩm bột cá là dưới $10-12 \%$, ở độ ẩm này thích hợp cho quá trình bảo quản, chất lượng sản phẩm bột cá ít bị biến đổi cũng như tránh sự hút ẩm trở lại gây vón cục, hư hỏng. Vậy thông số thích hợp để sản xuất bột đạm từ thịt vụn trên xương cá thác lác có độ ẩm phù hợp, hàm lượng đạm và hiệu suất thu hồi cao là sấy 2 ngày ở nhiệt độ $60^{\circ} \mathrm{C}$.

\section{5. Ảnh hưởng thời gian sấy đến chất lượng bột canxi}

Độ ẩm, độ hòa tan và hiệu suất thu hồi của sản phẩm bột canxi ở các mốc thời gian sấy khác nhau được thể hiện ở Bảng 6 . 
Bảng 5. Ảnh hưởng của thời gian sấy đến độ ẩm, hàm lượng protein và hiệu suất thu hồi của sản phẩm bột đạm

\begin{tabular}{ccccc}
\hline Mẫu & Thời gian sấy (ngày) & Độ ẩm $(\%)$ & Hàm lượng protein $(\%)$ & Hiệu suất thu hồi $(\%)$ \\
\hline 1 & 1 & $12,2 \pm 0,773^{\mathrm{c}}$ & $66,3 \pm 0,127^{\mathrm{a}}$ & $2,25 \pm 0,013^{\mathrm{a}}$ \\
2 & 2 & $9,11 \pm 1,01^{\mathrm{b}}$ & $68,1 \pm 0,989^{\mathrm{a}}$ & $2,19 \pm 0,102^{\mathrm{a}}$ \\
3 & 3 & $6,36 \pm 0,006^{\mathrm{a}}$ & $78,2 \pm 1,421^{\mathrm{b}}$ & $2,14 \pm 0,006^{\mathrm{a}}$ \\
\hline
\end{tabular}

a-c Trong cùng một cột, những số có chữ theo sau khác nhau thì có khác biệt ý nghĩa thống kê ở mức $5 \%$.

Bảng 6. Ảnh hưởng của thời gian sấy đến độ ẩm, độ hòa tan và hiệu suất thu hồi của sản phẩm bột canxi

\begin{tabular}{ccccc}
\hline Mẫu & Thời gian sấy (giờ) & Độ ẩm $(\%)$ & Độ hòa tan $(\%)$ & Hiệu suất thu hồi $(\%)$ \\
\hline 1 & 2 & $15,2 \pm 0,027^{\mathrm{c}}$ & $10,6 \pm 2,09^{\mathrm{a}}$ & $21,3 \pm 0,058^{\mathrm{c}}$ \\
2 & 3 & $11,4 \pm 1,40^{\mathrm{b}}$ & $13,2 \pm 2,02^{\mathrm{ab}}$ & $18,6 \pm 0,038^{\mathrm{b}}$ \\
3 & 4 & $7,76 \pm 0,086^{\mathrm{a}}$ & $17,4 \pm 2,08^{\mathrm{b}}$ & $15,1 \pm 0,077^{\mathrm{a}}$ \\
\hline${ }^{\mathrm{a}-\mathrm{c}}$ Trong cùng một cột, những số có chữ theo sau khác nhau thì có khác biệt ý nghĩa thống kê ở mức $5 \%$.
\end{tabular}

Bảng 7. Thành phần hóa học và vi sinh của bột đạm và bột khoáng (theo khối lượng khô)

\begin{tabular}{lcc}
\hline Chỉ tiêu phân tích & Bột đạm & Bột khoáng \\
\hline Hàm lượng canxi (\%) & KTH & 21,9 \\
Vi sinh $(\mathrm{cfu} / \mathrm{g})$ & $2,83 \times 10^{4}$ & $1,49 \times 10^{3}$ \\
Ẩm độ (\%) & $9,11 \pm 1,01$ & $11,4 \pm 1,40$ \\
Khoáng (\%) & $3,42 \pm 0,027$ & $77,6 \pm 0,141$ \\
Protein (\%) & $68,1 \pm 0,989$ & $7,33 \pm 0,011$ \\
Lipid (\%) & $12,4 \pm 0,424$ & $2,44 \pm 0,056$ \\
\hline
\end{tabular}

KTH: không thực hiện.

Từ Bảng 6 cho thấy, sấy mẫu xương cá ở $60^{\circ} \mathrm{C}$ khi tăng thời gian từ 2 đến 4 giờ thì hàm lượng ẩm giảm từ 15,2 còn $7,76 \%$, hiệu suất thu hồi giảm từ 21,3 còn $15,1 \%$, sự khác biệt có ý nghĩa thống kê giữa các mẫu. Do tác dụng nhiệt độ cao, càng tăng thời gian sấy thì nước tự do trong sản phẩm sẽ thoát ra càng nhiều vì vậy độ ẩm càng giảm và hiệu suất thu hồi càng thấp (Nguyen, 1990). Độ hòa tan tăng theo thời gian sấy từ 10,6 đến 17,4\% vì sấy càng lâu độ ẩm càng thấp, bột sẽ càng mịn giúp dễ dàng hòa tan trong nước hơn. So với kết quả của Hemung (2013) thì độ hòa tan của bột canxi từ xương cá rô phi là $9,38 \%$ và thấp hơn so với xương cá thát lát còm trong nghiên cứu này. Độ ẩm thích hợp để bảo quản bột canxi là dưới $10-12 \%$ (Le, 2014). Độ ẩm thấp cũng cho phép bột xương cá chống lại sự phát triển của vi sinh vật (Hemung, 2013). Vì vậy, thời gian sấy thích hợp là 3 giờ ở $60^{\circ} \mathrm{C}$ cho bột khoáng với chất lượng tốt nhất có độ ẩm, độ hòa tan và hiệu suất thu hồi thích hợp lần lượt là 11,4; 13,2 và 18,6\%.

\subsection{Thành phần hóa học của bột đạm và bột khoáng}

Chất lượng bột đạm và bột khoáng từ xương cá thát lát được thể hiện ở Bảng 7 .

Sản phẩm bột đạm tạo ra có hàm lượng ẩm thấp $(9,11 \%)$ đạt yêu cầu về độ ẩm nhỏ hơn $10 \%$, đây là cơ sở giúp tránh được các hiện tượng hư hỏng khi bảo quản và hạn chế tốc độ phát triển của vi sinh vật gây hỏng do sản phẩm có hoạt độ nước thấp ở độ ẩm này, tạo môi trường không thuận lợi cho vi sinh vật phát triển. Đồng thời, hàm lượng đạm của sản phẩm đạt tương đối cao $(68,1 \%)$, tuy nhiên vẫn chưa đạt yêu cầu của bột cá thực phẩm (hàm lượng đạm lớn hơn 70\%). Đối với sản phẩm bột khoáng từ xương cá thát lát có hàm lượng ẩm là $11,4 \%$ phù hợp để bảo quản trong thời gian dài và hàm lượng canxi có trong sản phẩm cũng tương đối cao $(21,9 \%)$ (Bảng 7). Cả bột đạm và bột khoáng từ xương cá thát lát đều có tổng vi sinh vật hiếu khí phù 
hợp, không vượt quá 106 cfu/g theo quy định của $\mathrm{MOH}$ (2007) thích hợp để bổ sung vào thức ăn chăn nuôi, riêng bột khoáng có thể bổ sung vào nguồn thực phẩm, tuy nhiên nếu muốn bổ sung vào thực phẩm thì cần nghiên cứu kỹ về khả năng hấp thụ của cơ thể để có chế độ bổ sung tốt nhất.

\section{Kết Luận}

Qua kết quả nghiên cứu cho thấy rằng khi thủy phân xương cá thác lác còm bằng enzyme Tegalase ở nồng độ $0,3 \%$ trong 24 giờ ở $50^{\circ} \mathrm{C}$ cho khả năng thủy phân cao nhất. Dịch thủy phân được nâng nhiệt trong thời gian 2 phút có hàm lượng đạm amin cao nhất là $18,1 \%$. Sản phẩm bột đạm thu được đạt độ ẩm thích hợp khi sấy ở $60^{\circ} \mathrm{C}$ trong thời gian là 48 giờ và cùng điều kiện sấy $60^{\circ} \mathrm{C}$ trong thời gian 3 giờ sẽ thu được bột khoáng với ẩm độ dưới $12 \%$.

\section{Lời Cảm Ơn}

Đề tài này được tài trợ bởi Dự án Nâng cấp Trường Đại học Cần Thơ VN14-P6 bằng nguồn vốn vay $\mathrm{ODA}$ từ Chính phủ Nhật Bản.

\section{Tài Liệu Tham Khảo (References)}

AOAC (Association of Official Analytical Chemists). (2016). Official Methods of Analysis of AOAC International $\left(20^{\text {th }}\right.$ ed.). Maryland, USA: AOAC International.

AOAC (Association of Official Analytical Chemists). (2000). Official methods of Analysis of AOAC International $\left(17^{\text {th }}\right.$ ed). Maryland, USA: AOAC International.

Bubel, F., Dobrzański, Z., Bykowski, P. J., Chojnacka, K., Opaliński, S., \& Trziszka, T. (2015). Production of calcium preparations by technology of saltwater fish by product processing. De Gruyter Open 13(1), 13331340 .

Dang, H. T. (2008). Evaluation of using protease enzyme in chitin - chitosan production process. (Unpublished master's thesis). Nha Trang University, Nha Trang, Vietnam.

Do, S. T., Nguyen, D. X., \& Nguyen, H. T. M. (2013). Study on hydrolysis of the seabass head (Lates calcarifer) by flavourzyme. Journal of Fisheries Science and Technology 1, 138-144.

Gao, M. T., Hirata, M., Toorisaka, E., \& Hano, T. (2006). Acid hyprolysis of fish wastes for lactic acid fermentation. Bioresource Technology 97(18), 2414-2420.

Guérard, F., Guimas, L., \& Binet, A. (2002). Production of tuna waste hydrolysates by a commercial neutral protease preparation. Journal of Molecular Catalysis B: Enzymatic 19-20, 489-498.
Hamada, M., Nagai, T., Kai, N., Tanoue, Y., Mae, H., Hashimoto, M., Miyoshi, K., Kumagai, H., \& Saeki, K. (1995). Inorganic constituents of bone of fish. Fisheries Science 61(3), 517-520.

Hemung, B. O. (2013). Properties of tilapia bone powder and its calcium bioavailability based on transglutaminase assay. International Journal of Bioscience, Biochemistry and Bioinformaticds 3(4), 306-309.

Hultmann, L., Phu, T. M., Tobiassen, T., Aas-Hansen, $\varnothing ., \&$ Rustad, T. (2012). Effects of pre-slaughter stress on proteolytic enzyme activities and muscle quality of farmed Atlantic cod (Gadus morhua). Food chemistry 134(3), 1399-1408.

Kristinsson, H. G., \& Rasco, B. A. (2000). Biochemical and fuctional properties of Atlantic salmon (Salmo salar) muscle proteins hydrolyzed with various alkaline proteases. Journal of Agricultural Food Chemistry 48(3), 657-666.

Le, T. N. (2002). Industrial biochemistry. Ha Noi, Vietnam: Science and Technics Publising House.

Le, T. T. M. (2014). Lectures: fishmeal oil and medicinal herb processing technology. Faculty of Fisheries, Can Tho University, Can Tho, Vietnam.

Liaset, B., Nortvedt, R., Lied, E., \& Espe, M. (2002). Studies on the nitrogen recovery in enzymic hydrolysis of Atlanticsalmon (Salmo salar, L.) frames by Protamex ${ }^{\mathrm{TM}}$ protease. Process Biochemistry 37, 12631269.

MOH (Ministry of Health). (2007). Decision No. 46/2007/QD-BYT dated 19/12/2007 on promulgation "Regulation of maximum level of biological and chemical pollution in food". Retrieved February 2, 2018, from http://www.fsi.org.vn/pic/files/462007qdbyt.pdf.

Muzaifa, M., Safriani, N., \& Zakaria, F. (2012). Production of protein hydrolysates from fish byproduct prepared by enzymatic hydrolysis. Aquaculture, Aquarium, Conservation \& Legislation - International Journal of the Bioflux Society 5(1), 36-39.

Nemati, M., Huda, N., \& Ariffin, F. (2017). Development of calcium supplement from fish bone wastes of yellowfin tuna (Thunnus albacares) and characterization of nutritional quality. International Food Research Journal 24(6), 2419-2426.

Nguyen, C. T. (1990). Technology of aquatic food processing vol. 2. Ho Chi Minh City, Vietnam: Agricultural Publishing House.

Nguyen, H. L. (2009). Hydrolysis of fish processing discard using enzyme from head of black tiger shrimp Penaeus monodon and process opmization. Journal of Fisheries Science and Technology 1, 10-18.

Nguyen, H. T. M., Sylla, K. S. B., Randriamahatody, Z., Donnay-Moreno, C., Moreau, J., Tran, L. T., \& Bergé, J. P. (2011). Enzymatic hydrolysis of yellowfin Tuna (Thunnus albacares) by-products using protamex protease. Food Technology and Biotechnology 49(1), 4855. 
Nguyen, H. T. N., Ngo, D. T. H., \& Ngo, N. D. (2013). Optimization of protein hydrolysis from white shirmp head (Penaeus vannamei) by alcalase adopting response surface methodology. Journal of Fisheries Science and Technology 2, 129-134.

Nguyen, L. D. (2004). Enzyme technology. Ho Chi Minh City, Vietnam: Ho Chi Minh City Vietnam National University Publishing House.

Ogawa, J., \& Shimizu, S. (2002). Industrial microbial enzymes: the discovery by screening and use in large scale production of useful chemicals in Japan. Current Opinion in Biotechnology 13(4), 367-375.

TCVN (Vietnamese National Standards). (2018). TCVN 3708-1990: Fisheries - Methods for determination of amino acid nitrogen content. Retrieved April 23, 2018, from https://vanbanphapluat.co/tcvn-37081990-thuy-san-phuong-phap-xac-dinh-ham-luongnito-axit-amin.
Techochatchawal, K., Therdthai, N., \& Khotavivattana, S. (2009). Development of calcium supplement from the bone of Nile Tilapia (Tilapia nilotica). Asian Journal of Food and Agro - Industry 2(4), 539-546.

Tran, D. (2014). Utilization of by-products from seafood processing. Retrieved July 25, 2017, from http://tomvang.com/tin-tuc/tan-dung-phu-pham-tuche-bien-thuy-san.

Vu, B. N. (2004). Protein hydrolysis by protease enzyme from Bacillus subtilis S5. (Unpublished doctoral dissertation). University of Science, Ho Chi Minh City, Vietnam. 